\title{
Modular endoprosthetic replacement for proximal tibia tumor patients
}

\section{Ye. Vyrva®*1,A,E,F, I. 0. Skoryk ${ }^{1, B, C, D}$, V. D. Tovazhnianska $\mathbb{1}^{2, C, E}$}

${ }^{1}$ Sytenko Institute of Spine and Joint Pathology National Academy of Medical Sciences of Ukraine, Kharkiv, ${ }^{2}$ Private Institution of Higher Education "Kharkiv International medical University”, Ukraine

A - research concept and design; B - collection and/or assembly of data; C - data analysis and interpretation; D - writing the article; $\mathrm{E}$ - critical revision of the article; $\mathrm{F}$ - final approval of the article

\section{Key words:} malignant bone tumors, modular endoprosthesis, proximal tibia.

\section{Zaporozhye} medical journal 2021; 23 (2), 242-249

*E-mail: dr.olegvyrva@gmail.com
The major method of malignant bone tumors treatment is surgery. The most important task of an orthopedic surgeon is to preserve an adjacent joint. Currently, there are a large number of various reconstructive surgeries, including structural bone allograft, allocomposite and modular endoprosthetics replacement.

The aim: to analyze the results of surgical treatment for proximal tibia malignant tumors using modular endoprosthesis.

Materials and methods. The results of proximal tibia (PT) modular endoprosthetic replacement in 48 patients with PT tumor lesions were evaluated. The patients were divided into two groups: I $(n=36)$ - tumor resection and primary modular endoprosthesis, II $(n=12)$ - revision modular endoprosthetic replacement due to complications. Complications were divided into oncological, mechanical and non-mechanical. The functional outcomes were measured using the MSTS and TESS scores.

Results. During the treatment, 10 (21.2\%) patients underwent myofascioplastic amputation at the middle third of the thigh: due to periprosthetic infection -8 people and tumor recurrence -2 .

It was found that the patients got back to regular way of life on average in 2.0-2.5 months. Functional results on the MSTS score were $73 \pm 12 \%$, on the TESS score $-74 \pm 16 \%$, which corresponds to good functional results. Among the patients, who underwent limb salvage surgery, no tumor recurrence was detected during a follow-up period from 6 months up to 11 years.

Conclusions. The choice of surgical treatment depends on the size of tumor, its location, pathohistomorphological picture, age, presence of pathological fractures, vascular and nerve tumor invasion. The use of modern designs of PT modular tumor endoprostheses and perfect surgeries makes it possible to minimize complications.
Кнючові слова: злоякісні пухлини кісток, моАульне ендопротезування, проксимальний BíAіı великогомілкової кістки.

Запорізький медичний журнал 2021. T. 23, № 2(125). C. 242-249

\section{Модульне ендопротезування проксимального відділу великогомілкової кістки в пацієнтів із пухиинним ураженням}

\section{0. Є. Вирва, І. О. Скорик, В. А. Товажнянська}

Основний метод лікування злоякісних пухлин кісток - хірургічне втручання. Найважливіше завдання ортопеда полягає у збереженні суглоба. Нині є велика кількість різноманітних реконструктивних операцій, включаючи структурну кісткову алопластику, алокомпозитне та модульне ендопротезування.

Мета роботи - проаналізувати результати хірургічного лікування злоякісних пухлин проксимального відділу великогомілкової кістки (ПВВК) із використанням модульного ендопротезування.

Матеріали та методи. Здійснили оцінювання результатів модульного ендопротезування ПВВК 48 пацієнтів із пухлинними ураженнями. Хворих поділили на дві групи: I ( $\mathrm{n}=36)$ - первинне модульне ендопротезування після видалення пухлини, II (n = 12) - ревізійне модульне ендопротезування з приводу ускладнень. Розрізняли онкологічні, механічні та немеханічні ускладнення. Функціональний результат оцінювали за допомогою шкал MSTS i TESS.

Результати. Під час лікування 10 (21,2\%) пацієнтам здійснили міофасціопластичну ампутацію на рівні середньої третини стегна: 8 хворим через перипротезну інфекцію, 2 особам у зв'язку із рецидивом пухлини.

Встановили, що в середньому за 2,0-2,5 місяця пацієнти поверталися до нормального життя. Функціональні результати за шкалою MSTS становили $73 \pm 12 \%$, за шкалою TESS - $74 \pm 16 \%$, і це відповідає хорошим фуннціональним результатам. У пацієнтів, яким виконали органозберігальну операцію, протягом періоду спостереження від 6 місяців до 11 років рецидиви пухлини не діагностували.

Висновки. Вибір хірургічного лікування залежить від розміру пухлини, локалізації, патогістоморфологічної картини, віку, наявності патологічних переломів, інвазії судин, нервів. Використання сучасних конструкцій модульних ендопротезів ПВВК і досконалих оперативних утручань дає можливість мінімізувати кількість ускладнень.

\section{Модульное эндопротезирование большеберцовой кости у пациентов с опухолевыми поражениями}

\section{О. Е. Вырва, И. А. Скорик, В. А. Товажнянская}

Основной метод лечения злокачественных опухолей костей - хирургическое вмешательство. Важнейшей задачей ортопеда является сохранение сустава. В настоящее время существует большое количество различных реконструктивных операций, включая структурную костную аллопластику, аллокомпозитное и модульное эндопротезирование. 
Цель работы -проанализировать результаты хирургического лечения злокачественных опухолей проксимального отдела большеберцовой кости (ПОБК) с использованием модульного эндопротезирования.

Материалы и методы. Проведена оценка результатов модульного эндопротезирования ПОБК 48 пациентов с опухолевыми поражениями. Пациентов поделили на две группы: I $(\mathrm{n}=36)$ - первичное модульное эндопротезирование после удаления опухоли, II (n = 12) - ревизионное модульное эндопротезирование по поводу осложнений. Осложнения разделяли на онкологические, механические и немеханические. Функциональный результат оценивали с помощью шкал MSTS и TESS.

Результаты. Во время лечения 10 (21,2%) пациентам проведена миофасциопластичная ампутация на уровне средней трети бедра: 8 обследованным в связи с перипротезной инфекцией, 2 больным в связи с рецидивом опухоли.

Установлено, что в среднем через 2,0-2,5 месяца пациенты возвращались к нормальной жизни. Функциональные результаты по шкале MSTS составили $73 \pm 12 \%$, по шкале TESS - $74 \pm 16 \%$, что соответствует хорошим фрункциональным результатам. Среди пациентов, перенесших органосберегающую операцию, в течение периода наблюдения от 6 месяцев до 11 лет рецидивы опухоли не обнаружены.

Выводы. Выбор хирургического лечения зависит от размера опухоли, ее локализации, патогистоморфологической картины, возраста, наличия патологических переломов, инвазии в сосуды и нервы. Использование современных конструкций модульных эндопротезов ПОБК и совершенных оперативных вмешательств позволяет минимизировать количество осложнений.

Nowadays, major method of malignant bone tumors treatment is surgery, and the most important task of a surgeon, in addition to removing the tumor, is to preserve the adjacent joint. Volume of surgery at this pathology depends on size of pathological focus and cortical layer integrity of the affected bone. This involves usage of various techniques - from partial resection to massive periarticular reconstructive surgery. Partial resection is an affordable method of surgery, but it is very difficult to completely remove a tumor using this method, even with modern tools. Therefore, there is a risk of tumor local recurrence. Thus, it is recommended to perform extensive resection or resection "en block", especially in case of local tumor recurrence, pathological fracture with aggressive course of malignant tumor. This method allows a tumor removal within healthy tissue, so that the tumor itself is not damaged and its cell dissemination does not occur, so the risk of recurrence is close to zero. However, after resection of the tumor, there is a large enough defect that requires immediate replacement. Currently, there are a large number of various reconstructive limb-salvage surgeries, including structural bone allograft, allocomposite and modular endoprosthetic replacement etc.

The proximal tibia (PT) is one of the most common sites for primary malignant bone tumors $[1,3]$. In this segment of skeleton, we observed up to $15 \%$ of all osteosarcomas, $11 \%$ of Ewing's sarcomas and $6 \%$ of chondrosarcomas $[5,6,11,15,27]$. By the end of 1970 s, above-knee amputation was the standard treatment procedure for PT malignant tumors [7,10,14-16]. Today, thanks to advances in radiological diagnostics, immunohistochemical studies, radical changes in general principles of treatment for primary malignant bone neoplasms, complex chemotherapy and improvement of surgeries it has changed. For example, technical modernization of endoprosthesis structures, organ-preserving surgery has become a standard method of treatment $[1,2,5,6,8,9,11,15,16,27,28]$. PT modular tumor endoprosthetic replacement is difficult to perform due to changeability of anatomical structure - there is a risk of injury of tibial nerve and popliteal vessels. Moreover, together with a complex surgical performance, there are problems with closing the defect with soft tissues [2-7,9,11-13,15]. For these reasons, the reconstruction of $\mathrm{PT}$ after tumor removal is associated with a large number of complications compared to other parts of the skeleton - from 40 to $70 \%$ according to different authors $[3,4,7,8,10,13,14,16,21,22,24-28]$.
These include infections, structural disorders, aseptic instability, local recurrence, and a number of soft tissue lesions [3,8,11,17-26]. To further standardize complications, E. R. Henderson et al. [8] proposed a classification that was adopted in 2014 by the International Society of Limb Salvage (ISOLS). According to it, complications related to soft tissue incontinence are classified as type 1, aseptic instability - type 2, endoprosthesis fracture and periprosthetic fractures - type 3, infection complication - type 4 and local recurrences - type 5.

\section{Aim}

To analyze the results of surgical treatment for proximal tibia malignant tumors using modular endoprosthesis.

\section{Materials and methods}

We evaluated results of surgeries (PT modular endoprosthesis) performed at Bone Tumor Department, Sytenko Institute of Spine and Joint Pathology, in 48 patients that had tumor lesions of PT. Patients' age ranged from 12 to 74 years old, among them, there were 20 men $(41.7 \%)$ and 28 women (58.3\%). Division by nosological groups is given in Table 1 .

Patients were divided into two groups: I (36 people) primary modular endoprosthesis after tumor removal, II (12 patients) - revision modular surgery for consequences of tumor endoprosthesis (patients with complications who underwent primary surgery in other hospitals).

During the surgery, we used modular endoprosthesis of different systems: Global Modular Reconstruction System (GMRS, Stryker, USA), Modular Universal Tumor and Revision System (MUTARS, Germany), System of Individual Modular Endoprostheses of Bones and Joints (SIMEX, Ukraine).

Complications that occurred after modular endoprosthesis were divided into oncological, mechanical and non-mechanical (Hendeson classification [8]). According to this classification, there were 5 types of complications:

I - associated with soft tissue failure (rupture of knee ligament, wound dehiscence and other defects of soft tissues);
II - aseptic instability;
III - structural disorders and periprosthetic fractures;

Ключевые слова: злокачественные опухоли костей, модульное энАопротезирование, проксимальный OTAеN большеберцовой кости. медицинский журнал. 2021. T. 23, № 2(125). C. 242-249 

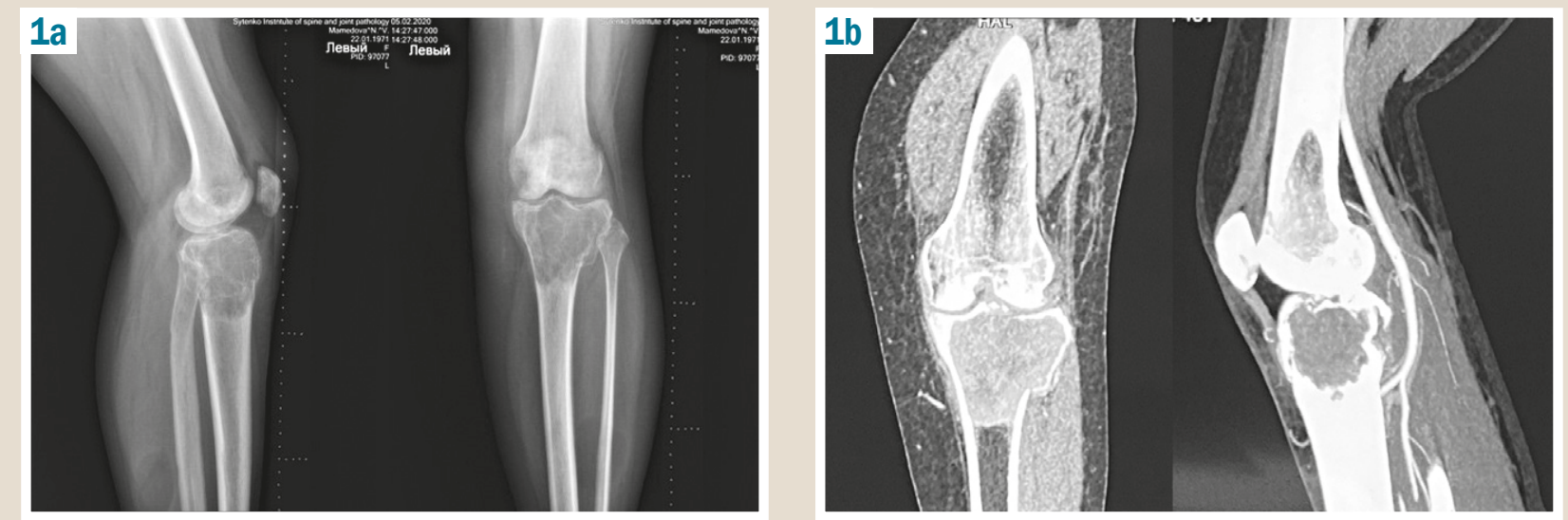

Fig. 1. X-ray images (a) and CT (b) of the PT, patient M., 49 years old.

Table 1. Division of patients by nosological groups

\begin{tabular}{l|ll} 
Nosology & $\begin{array}{l}\text { Group of patients } \\
\text { I (primary modular } \\
\text { endoprosthesis) }\end{array}$ & $\begin{array}{l}\text { II } \\
\text { (revision surgery) }\end{array}$ \\
\hline Chondroblastoma $(n=7)$ & 5 & 2 \\
\hline Desmoplastic fibroma $(n=1)$ & 1 & - \\
\hline Histiocytoma (undifferentiated pleomorphic & 4 & 2 \\
sarcoma) $(n=6)$ & & 2 \\
\hline Giant cell tumor $(n=18)$ & 16 & - \\
\hline Lymphoma $(n=1)$ & 1 & 5 \\
\hline Osteosarcoma $(n=12)$ & 7 & 1 \\
\hline Synovial sarcoma $(n=1)$ & - & - \\
Metastases $(n=2)$ & 2 & 12 \\
\hline Overall $(n=48)$ & 36 & \\
\hline
\end{tabular}

Table 2. Division of complications by type

\begin{tabular}{llll|l}
\multirow{2}{*}{ Type of complication } & \multicolumn{2}{|l|}{ Group of patients } & \multirow{2}{*}{ Total } \\
\cline { 2 - 3 } & I & II & \\
I & $1(2.78 \%)$ & $2(16.6 \%)$ & $3(6.25 \%)$ \\
II & $1(2.78 \%)$ & 0 & $1(2.08 \%)$ \\
III & 0 & 0 & 0 \\
IV & $9(25 \%)$ & $3(25 \%)$ & $12(25 \%)$ \\
V & $2(5.55 \%)$ & 0 & $2(4.17 \%)$ \\
\hline Overall & $13(36.1 \%)$ & $5(41.6 \%)$ & $18(37.5 \%)$ \\
\hline
\end{tabular}

IV - infection;

$\mathrm{V}$ - local tumor recurrence (Table 2).

During the treatment, $10(21.2 \%)$ patients underwent a myofascioplastic amputation at the middle third of the thigh: due to periprosthetic infection -8 people and tumor recurrence -2 .

Results were evaluated by modern bioethical requirements of the Sytenko Institute of Spine and Joint Pathology National Academy of Medical Sciences of Ukraine (protocol No. 174 29.01.2018, No. 201 02.03.2020).

The functional outcome was evaluated using the MSTS and TESS scores. The MSTS score [8] allows evaluating functional condition of a patient by a doctor after comprehensive treatment of the bone tumor. The TESS score [7] was developed to assess functional state of patient at home and it is more subjective in terms of patients' feelings. The results of both scores were evaluated as a percentage by the following gradations: excellent result - from $75 \%$ to $100 \%$, good -from $70 \%$ to $74 \%$, average -from $60 \%$ to $69 \%$, satisfactory - from $50 \%$ to $59 \%$, unsatisfactory - less $50 \%$.

The data were statistically processed using the Microsoft Excel licensed software package. We used the methods of variational and alternative analyzes. For the data we used Mann-Whitney $U$ test and Student criterion.

\section{Results}

As an analysis result, it was found that the patients got back to regular way of life on average in 2.0-2.5 months. Functional results on the MSTS score were $73 \pm 12 \%$, on the TESS score $-74 \pm 16 \%$, which corresponded to good functional results. Among the patients, who underwent limb-salvage surgery, no tumor recurrence was detected during a follow-up period from 6 months up to 11 years.

In our clinic, we use this kind of surgical treatment for PT tumors (III stage) because this method yields successful results. It helps to achieve full function of the knee joint in the shortest possible time.

A case report: a 49-year-old female patient $\mathrm{M}$. applied to the Sytenko Institute of Spine and Joint Pathology National Academy of Medical Sciences of Ukraine with severe pain under left knee. She had a history of slight pain for about 2 years. In the home area, she received treatment for left-sided gonarthrosis (anti-inflammatory therapy, chondroprotectors etc.) with no stable positive effect.

On November 14, 2019, she was injured following a fall, when a pathological fracture of PT was detected. After a comprehensive examination at the clinic, the patient was diagnosed with chondroblastoma of the left PT, stage III according to the Enneking classification. The pathological fracture of the left PT is presented in Fig. 1. A surgery was performed: removal of PT tumor "en block" (segmental resection), replacement of the post-resection PT defect with modular endoprosthesis (Fig. 2). During the surgery, we performed a reattachment of the musculofascial complex to an attachment tube (Fig. 3, a). The next surgery step was a reattachment of the left knee extensor apparatus (Fig. 3, b) and fixation of the patella ligament to the attachment tube (Fig. 3, c). The next step was a suture fixation the knee joint capsule (Fig. 3, d). 

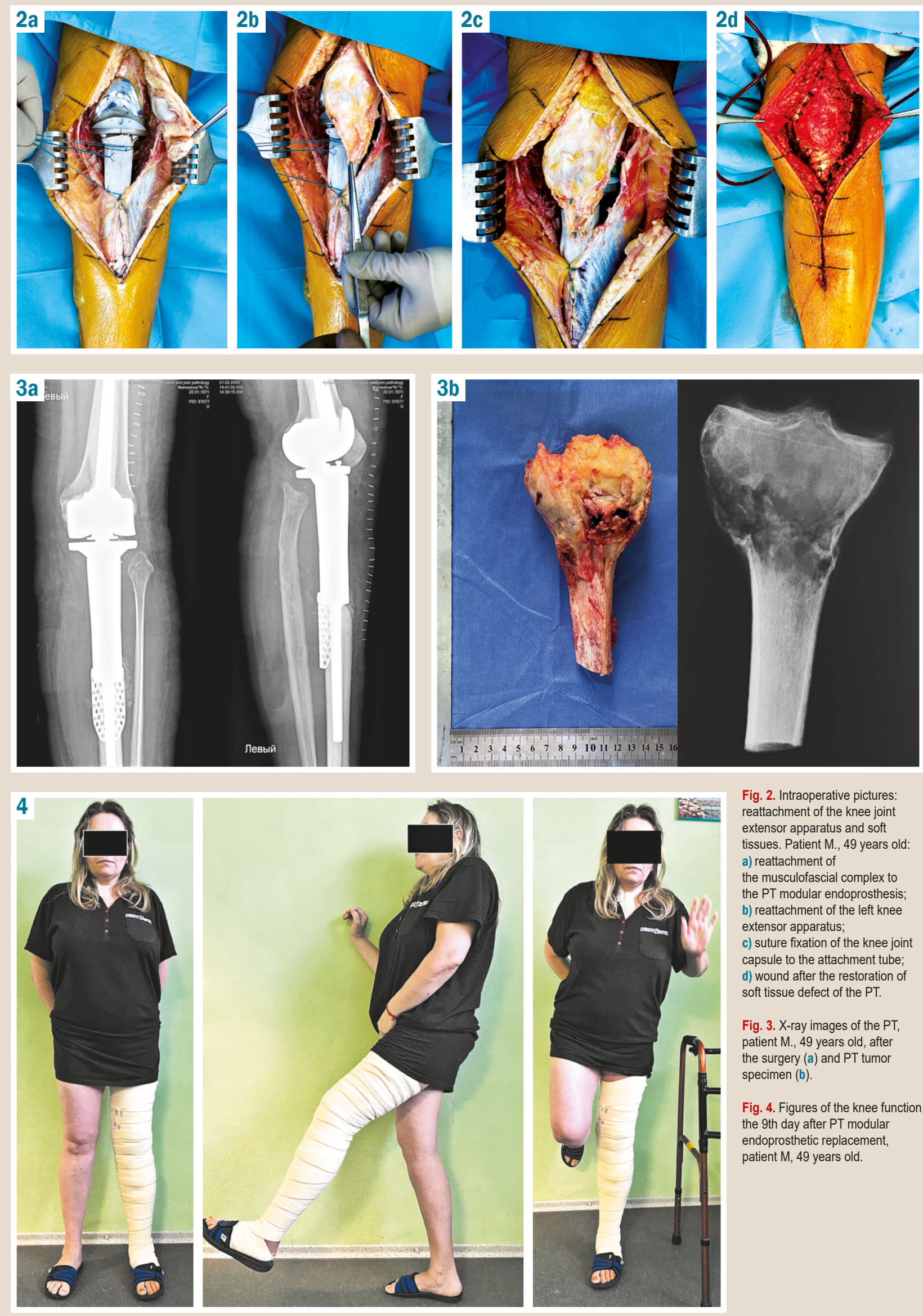

Fig. 2. Intraoperative pictures: reattachment of the knee joint extensor apparatus and soft issues. Patient M., 49 years old: a) reattachment of the musculofascial complex to the PT modular endoprosthesis b) reattachment of the left knee extensor apparatus: c) suture fixation of the knee joint capsule to the attachment tube: d) wound after the restoration of soft tissue defect of the PT.

Fig. 3. X-ray images of the PT, patient M., 49 years old, after the surgery (a) and PT tumor specimen (b).

Fig. 4. Figures of the knee function, the 9th day after PT modular endoprosthetic replacement, patient M, 49 years old. 


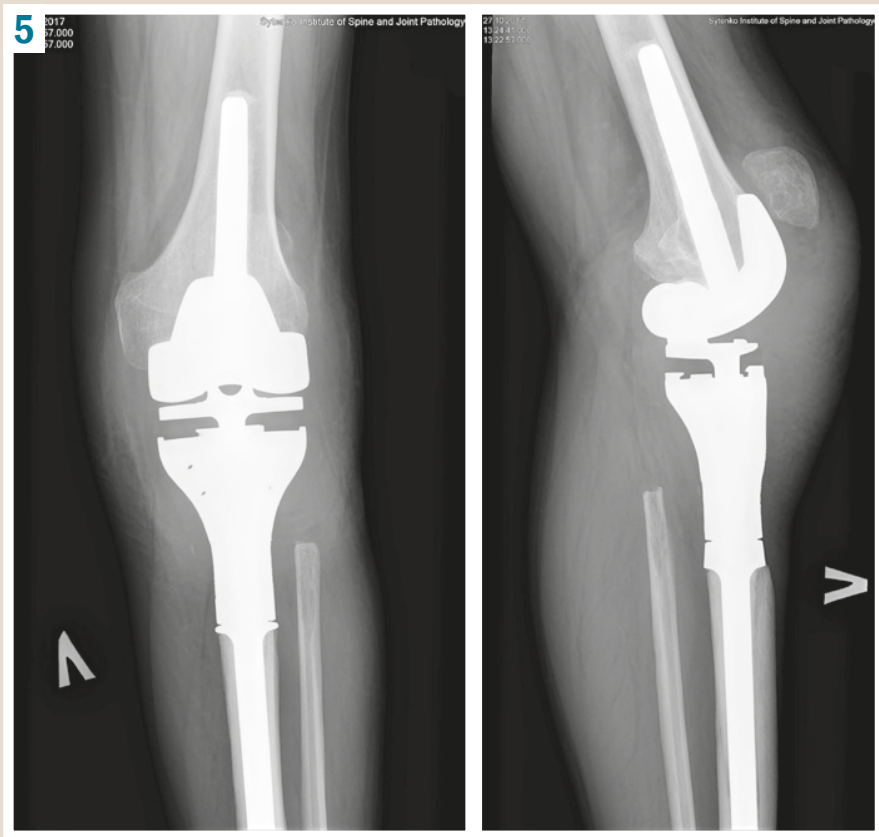

Fig. 5. X-ray images with knee ligament detachment after primary endoprosthetic replacement using the GMRS system (Stryker, USA)

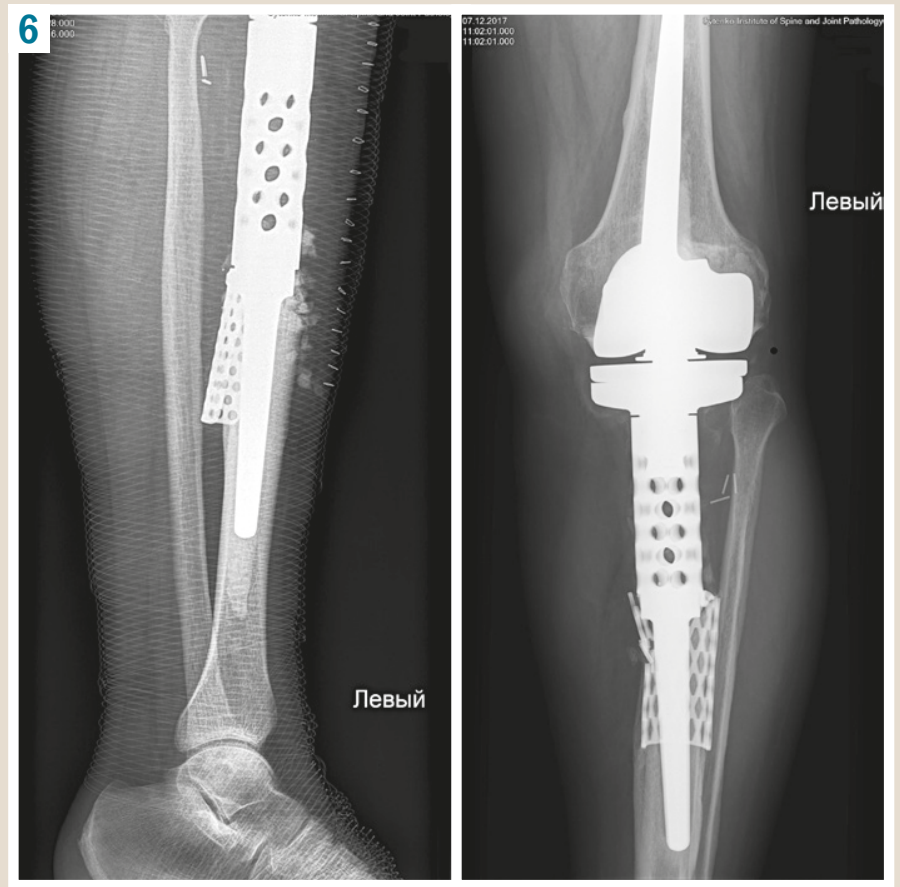

Fig. 6. X-ray images: aseptic instability of the tibial stem endoprosthesis.

9 days after the surgery, the patient was able to walk without support (Fig. 4). The full range motion was achieved in 4 weeks after the surgery. Two months after the surgery, the patient returned to daily life activities.

A revision surgery was performed in 18 (38.5\%) cases during a period from 3 weeks to 13 years after PT modular endoprosthesis implantation due to complications. Moreover, in 12 cases (25\%), we had to perform an originally implanted endoprosthesis removal with a metal-cement spacer replacement of the bone and joint defect: in group I $-9(25 \%)$, in group II $-3(25 \%)$. Two $(4.17 \%)$ myofascioplastic amputations were performed for tumor recurrence.

Complications associated with soft tissue failure. Type I complications were registered in $3(6.25 \%)$ patients: in group I -1 (2.78 \% of all group complications), 6 months after the PT modular endoprosthetic replacement, in group II - 2 (16.6\%), in 2 weeks and 1 year, respectively. In all the observations, the endoprosthesis was preserved. Among the complications, we observed 3 cases of knee ligament detachment (Fig. 5). In our opinion, this happened due to an orthopedic regime violation by a patient.

The surgery involved fixing knee ligament to proximal module of the tibial endoprosthesis. Knee ligament fixation was performed using the attachment tube (manufactured by Implantcast, Germany) or a nylon tape (manufactured by Ethicone, J\&J) with a duplication of the knee ligament from the knee joint capsule.

One patient in group II showed formation of a stable extensor contracture of the knee joint. We consider a soft tissue fibrotization as a cause of it. After all, each surgery is a significant injury to a segment or limb, and given a presence of infection in this area in a past history, the formation of massive scars in such a case is inevitable.

Aseptic instability of the endoprosthesis (type /I complications) according to our data was detected in only 1 patient $(2.78 \%) 6$ years after the primary PT modular endoprosthetic replacement. The patient was initially fitted with cementless ceramic-coated endoprosthesis stem. An interesting fact was a usage in the tibial component design of extramedullary plate with a ceramic coating, which was firmly fused with tibia and soft tissues around it. As a result of the limb functional activity after the surgery, the metal plate could not withstand load, which led to extramedullary fracture and aseptic instability of the tibia endoprosthesis (Fig. 6). In this case, a revision surgery was performed, the endoprosthetic tibial component was replaced without removing the attachment tube. The knee extensor apparatus and knee joint capsule were fixed to it during surgery. Performed manipulations made possible a full weight bearing and active knee range of motion at the shortest time (on the $3^{\text {rd }}$ day) after the surgery.

Mechanical complications, such as periprosthetic fractures, fractures of the endoprosthesis components (type III) were not observed in our study.

Type IV complications - periprosthetic infection was detected in 12 patients out of 48 , ie $25 \%$ of all complications. The terms of its development ranged from 12 days to 4 years. In group I, 9 (25\%) cases were registered, in group II $-3(25 \%)$. In all the patients, during the first stage of revision surgery, we removed the implant and performed radical surgical treatment of wound with an excision of pathologically altered tissues, active "pulse lavage" wound debridement and implantation of a metal-cement spacer VancoGenx (manufactured by Tecres, Italy), loaded with two antibiotics - Vankomicin and Gentamicin. In 6-8 months after the revision surgery, during the second stage, we performed revision PT modular endoprosthetic replacement. All cases during postoperative period were accompanied by prolonged extensor contracture of the knee joint.

Eight patients underwent the myofascioplastic amputation at the middle third of the thigh due to severe generalized 
infection with complex defects of soft tissues which could not be treated with the limb salvage procedures.

Type $V$ complications. Local tumor recurrence was detected in 2 (5.55\% of all complications) patients of group I: 6 months after surgery in patients with low-grade chondrosarcoma of the proximal tibia; 3 years after the surgery in patient with osteosarcoma of the proximal tibia. Both patients underwent the myofascioplastic amputation at the middle third of the thigh.

\section{Discussion}

Currently, in our opinion, only type of surgery during malignant PT tumor is "en block" tumor resection. However, after such surgical procedure, an onco-orthopedist must solve a problem of a large volume defect replacement. Today, structural allografts, modular and allocomposite endoprostheses are used for this purpose. Each of these methods has certain advantages and disadvantages. Complications include non-oncological ones such as infections, allograft resorption, soft tissue failure, and so on. In our experience, in case of massive defects formed after tumor removal, the most effective method of surgery is modular endoprosthetic replacement, which allows to perform ablastic tumor removal and in the shortest possible time to activate patients for their limb function restoration $[2,4,9,11,20]$.

An experimental study (laboratory rats) was conducted on the basis of Sytenko Institute of Spine and Joint Pathology. We proved expediency of using polyethylene terephthalate for fixation of soft tissues, as only this material use allows preserving anatomical structures as much as possible. In addition, in case of extensor apparatus fixation of the knee joint, only in polyethylene terephthalate use, tendon-like tissue is formed in the area of knee ligament attachment [3,11,13,17-20].

Modular tumor endoprosthesis is a system without ability to self-regulate with limited using. No matter how perfect the implanted structure is, it will always be a foreign body for human organism, which it will try to separate (forming a dense connective tissue capsule) or reject, in case of an immunoconflict reaction. Therefore, it is very difficult to single out one main reason that could lead to the development of a certain complication. It is only possible to name the factors of conflict between the implant and patient's body that caused the development of complications.

Failure of the knee joint extensor apparatus, according to the literature, is observed in about $5.8-12.0 \%$ of cases of all complications in the PT area [3,7,8,15,16,22-24]. Based on the results of our study, they were detected in $6.25 \%$ of all surgical procedures and were caused by a sharp flexion of the knee joint with a simultaneous load on the limb.

Modular endoprosthesis tibial stem aseptic instability was observed in 1 case, which amounted to $2.08 \%$ of complications among all surgical interventions. Mavrogenis A. F. et al. [13] reported aseptic instability in approximately $6 \%$ of cases with PT modular endoprostheses. Under conditions of this complication, there is a pain syndrome in the lower limb, the only method of treatment is revision surgery with the replacement of endoprosthesis. This volume of surgery is standard in the case of aseptic instability.

Mechanical complications were not detected in our study in any of systems of tumor endoprostheses. Although according to published data, they occur quite often - from $2 \%$ to $12 \%[3,7,8,15,16,23]$. The loads that happen at friction node of the knee endoprosthesis are usually 20-40 times higher than that at a healthy knee joint, depending on a hinge design. Any breakage in this part of the endoprosthesis requires revision surgery.

Periprosthetic infection is the most common complication, which, according to various authors, happens from $11 \%$ to $36 \%[3,7,8,15,16,23,27,28]$. Among our patients, infectious complications were detected in 12 people (25.5\%). In the standards of the PT reconstruction during deficiency of soft tissues, it is recommended to initially use the gastrocnemius muscle flap to cover the endoprosthesis, as a protection against possible skin injury and to reduce a risk of trophic disorders in this area. However, we did not find any association with infection progression depending on the use of the muscle flap. It should be noted that infectious complications in both groups were almost the same share-about $25 \%$.

Acute and chronic infectious processes cause different approaches to treatment. Acute infectious complications included suppurations that developed during the first 3 weeks after primary surgery, chronic ones included deeper and destructive inflammatory processes that were diagnosed after this period.

In the case of an acute infectious complication, such treatment methods as open debridement, wound lavage, long-term washing of the joint cavity with antiseptics, massive antibacterial therapy, VAC therapy, etc. can be used. Some authors even recommend one-stage revision endoprosthetic replacement, although positive results, according to various sources, are observed only in 27-30\% of patients $[3,7,15,16,23]$. In case of purulent complications treatment that developed in the late period, these methods did not lead to positive results, so optimal combination of antimicrobial therapy, radical surgical treatment of infection lesions with mandatory removal of implants and bone cement, implantation of temporary metal-cement spacers combined with adequate drainage and detoxification therapy is needed [3,7,8,15,16,22-24].

In our study, the surgeries were performed, which provided a comprehensive approach to treatment of infection, taking into account modern technologies. However, the number of cases that were accompanied by a long-term infectious process and ended in amputation, was quite large -8 patients.

Local tumor recurrence was detected in 2 patients (5.55\% of all complications and $4.25 \%$ of all cases), which was due to the primary type of tumor, late treatment of patient in a specialized hospital and difficult clinical situation. All the patients underwent amputation of the affected limb with subsequent prosthetics. In such cases, there was a very high risk of tumor recurrence after revision surgery, so it was considered inappropriate. According to modern treatment standards and designs of new exoprostheses, amputation at the thigh level is the method of choice.

\section{Conclusions}

1. Treatment of primary malignant $P T$ tumors is a complex problem, the study of which must not stop today. The choice of surgical treatment depends on the tumor volume, 
tumor site, pathohistomorphological picture, patient's age, presence of pathological fractures, vascular and nerve tumor invasion. The use of modern designs of PT modular tumor endoprostheses and perfect surgeries makes it possible to minimize mechanical complications.

2. Clinical analysis of treatment results among 48 patients with malignant PT tumors shows that resection "en block" allowed to avoid oncological complications during the follow-up period from 6 months up to 14 years. The use of modular endoprostheses, reinsertion of soft tissues on body of endoprosthesis and knee extensor apparatus reattachment after tumor removal, as well as early activation of a patient contributed to a good functional result on the MSTS score $73 \pm 12 \%$ and on the TESS score $-74 \pm 16 \%$.

3. The most complex and common complication was early and late periprosthetic infection.

4. Adequate fixation of the knee joint extensor apparatus gave patients the opportunity to obtain a good functional result on the MSTS score $72 \pm 12 \%$ and on the TESS score $-74 \pm 16 \%$ of cases.

5. Despite the number of complications and complexity of surgery in patients with malignant PT tumors, the method of replacing post-resection defects with modular endoprostheses is justified, as it allows to obtain $61.8 \%$ of positive results, as evidenced by the clinical study.

Conflicts of interest: authors have no conflict of interest to declare. Конфмікт інтересів: віАсутній.

Надійшла Ао реАакції / Received: 18.11 .2020

Після Аоопрацювання / Revised: 30.11 .2020

Прийнято АО Аруку / Accepted: 04.12.2020

Information about authors:

Vyrva O. Ye., MD, PhD, DSc, Professor, Chief Medical Officer, Head of the Bone Tumor Department, Sytenko Institute of Spine and Joint Pathology National Academy of Medical Sciences of Ukraine, Kharkiv.

ORCID ID: 0000-0003-0597-4472

Skoryk I. O., MD, PhD student, Sytenko Institute of Spine and Joint Pathology National Academy of Medical Sciences of Ukraine, Kharkiv.

ORCID ID: 0000-0002-4340-9186

Tovazhnianska V. D., MD, PhD, Assistant of the Department of Professionally Oriented Disciplines, Private Institution of Higher Education “Kharkiv International medical University”, Ukraine. ORCID ID: 0000-0002-4340-9186

\section{Відомості про авторів:}

Вирва О. Є., А-р меА. наук, професор, головний лікар, зав. відАілу кісткової онкології, АУ «Інститут патології хребта та суглобів імені професора М. І. Ситенка НАМН України", м. Харків.

Скорик І. О., аспірант, АУ «Інститут патології хребта та суглобів імені професора М. І. Ситенка НАМН України", м. Харків. Товажнянська В. А., канА. меА. наук, асистент каф. професійноорієнтованих Аисциплін, ПВНЗ «Харківський міжнароАний медичний університет", Україна.

Сведения об авторах:

Вырва О. Е., А-р меА. наук, профессор, главный врач, зав. отАелом костной онкологии, ГУ «Институт патологии позвоночника и суставов имени профессора М. И. Ситенко НАМН Украины", г. Харьков.

Скорик И. А., аспирант, ГУ «Институт патологии позвоночника и суставов имени профессора М. И. Ситенко НАМН Украины", г. Харьков.
Товажнянская В. А., канА. меА. наук, ассистент каф. профессионально-ориентированных Аисциплин, ЧВуу "Харьковский международный медицинский университет", Украина.

\section{References}

[1] Albergo, J. I., Gaston, C. L., Aponte-Tinao, L. A., Ayerza, M. A., Muscolo, D. L., Farfalli, G. L., Jeys, L. M., Carter, S. R., Tillman, R. M., Abudu, A. T., \& Grimer, R. J. (2017). Proximal Tibia Reconstruction After Bone Tumor Resection: Are Survivorship and Outcomes of Endoprosthetic Replacement and Osteoarticular Allograft Similar? Clinical Orthopaedics and Related Research, 475(3), 676-682. https:/l doi.org/10.1007/s11999-016-4843-y

[2] Bates, N. A., Myer, G. D., Shearn, J. T., \& Hewett, T. E. (2015). Anterior cruciate ligament biomechanics during robotic and mechanical simulations of physiologic and clinical motion tasks: a systematic review and meta-analysis. Clinical Biomechanics, 30(1), 1-13. https://doi. org/10.1016/j.clinbiomech.2014.12.006

[3] Bus, M. P., van de Sande, M. A., Fiocco, M., Schaap, G. R., Bramer, J. A., \& Dijkstra, P. D. (2017). What Are the Long-term Results of MUTARS $\otimes$ Modular Endoprostheses for Reconstruction of Tumor Resection of the Distal Femur and Proximal Tibia? Clinical Orthopaedics and Related Research, 475(3), 708-718. https://doi.org/10.1007/ s11999-015-4644-8

[4] Calori, G. M., Mazza, E. L., Vaienti, L., Mazzola, S., Colombo, A., Gala, L., \& Colombo, M. (2016). Reconstruction of patellar tendon following implantation of proximal tibia megaprosthesis for the treatment of post-traumatic septic bone defects. Injury, 47(Suppl. 6), S77-S82. https://doi.org/10.1016/S0020-1383(16)30843-9

[5] Donati, D., Colangeli, M., Colangeli, S., Di Bella, C., \& Mercuri, M. (2008). Allograft-Prosthetic Composite in the Proximal Tibia After Bone Tumor Resection. Clinical Orthopaedics and Related Research, 466(2), 459-465. https://doi.org/10.1007/s11999-007-0055-9

[6] Gottsauner-Wolf, F., Kotz, R., Knahr, K., Kristen, H., Ritschl, P., \& Salzer, M. (1991). Rotationplasty for limb salvage in the treatment of malignant tumors at the knee. A follow-up study of seventy patients. The Journal of Bone \& Joint Surgery, 73(9), 1365-1375.

[7] Henderson, E. R., Groundland, J. S., Pala, E., Dennis, J. A., Wooten, R. Cheong, D., Windhager, R., Kotz, R. I., Mercuri, M., Funovics, P. T., Hornicek, F. J., Temple, H. T., Ruggieri, P., \& Letson, G. D. (2011). Failure Mode Classification for Tumor Endoprostheses: Retrospective Review of Five Institutions and a Literature Review. The Journal of Bone \& Joint Surgery, 93(5), 418-429. https://doi.org/10.2106/JBJS.J.00834

[8] Henderson, E. R., O'Connor, M. I., Ruggieri, P., Windhager, R., Funovics, P. T., Gibbons, C. L., Guo, W., Hornicek, F. J., Temple, H. T., \& Letson, G. D. (2014). Classification of failure of limb salvage after reconstructive surgery for bone tumours: a modified system Including biological and expandable reconstructions. The Bone \& Joint Journal, 96-B(11), 1436-1440. https://doi.org/10.1302/0301-620X.96B11.34747

[9] Ichikawa, J., Matsumoto, S., Shimoji, T., Ae, K., Tanizawa, T., \& Gokita, T. (2015). A new technique using mesh for extensor reconstruction after proximal tibial resection. The Knee, 22(6), 659-663. https://doi. org/10.1016/.jknee.2015.01.001

[10] Jeys, L. M., Grimer, R. J., Carter, S. R., \& Tillman, R. M. (2005). Periprosthetic Infection in Patients Treated for an Orthopaedic Oncological Condition. The Journal of Bone \& Joint Surgery, 87(4), 842-849. https:// doi.org/10.2106/JBJS.C.01222

[11] Liu, B., Tan, J. C., Wang, H. L., Wu, Z., Yuan, Z. C., \& Wei, C. Y. (2019). The role of mesh technology with tumor prosthesis reconstruction to reconstruct the extensor mechanism of knee joint after resection of proximal tibial tumors. Journal of Orthopaedic Surgery and Research, 14(1), Article 64. https://doi.org/10.1186/s13018-019-1105-1

[12] Loudon, J. K. (2016). Biomechanics and pathomechanics of the patellofemoral joint. International journal of sports physical therapy, 11(6), 820-830.

[13] Mavrogenis, A. F., Pala, E., Angelini, A., Ferraro, A., \& Ruggieri, P. (2013). Proximal Tibial Resections and Reconstructions: Clinical Outcome of 225 Patients. Journal of Surgical Oncology, 107(4), 335342. https://doi.org/10.1002/iso.23216

[14] Pala, E., Trovarelli, G., Calabrò, T., Angelini, A., Abati, C. N., \& Ruggieri, P. (2015). Survival of Modern Knee Tumor Megaprostheses: Failures, Functional Results, and a Comparative Statistical Analysis. Clinical Orthopaedics and Related Research, 473(3), 891-899. https:// doi.org/10.1007/s11999-014-3699-2

[15] Picci, P., Manfrini, M., Fabbri, N., Gambarotti, M., \& Vanel, D. (Eds.). (2014). Atlas of Musculoskeletal Tumors and Tumorlike Lesions. Springer International Publishing. https://doi.org/10.1007/978-3-319-01748-8

[16] Puchner, S. E., Kutscha-Lissberg, P., Kaider, A., Panotopoulos, J., Puchner, R., Böhler, C., Hobusch, G., Windhager, R., \& Funovics, P. T. (2015). Outcome after Reconstruction of the Proximal Tibia - Com- 
plications and Competing Risk Analysis. PLOS ONE, 10(8), Article e0135736. https://doi.org/10.1371/journal.pone.0135736

[17] Sharma, A., \& Komistek, R. D. (2018). Contact Mechanics of the Human Knee. In W. N. Scott, D. R. Diduch, R. lorio, \& J. W. Long (Eds.), Insall \& Scott Surgery of the Knee (6th ed., Vol. 1, pp. 329-337.e1). Elsevier.

[18] Sigal, I. R., Grande, D. A., Dines, D. M., Dines, J., \& Drakos, M. (2016). Biologic and Tissue Engineering Strategies for Tendon Repair. Regenerative Engineering and Translational Medicine, 2(3-4), 107-125. https://doi.org/10.1007/s40883-016-0019-2

[19] Smolle, M. A. Andreou, D., Tunn, P. U., \& Leithner, A. (2019). Advances in tumour endoprostheses: a systematic review. EFORT Open Reviews, 4(7), 445-459. https://doi.org/10.1302/2058-5241.4.180081

[20] Snedeker, J. G., \& Foolen, J. (2017). Tendon injury and repair - A perspective on the basic mechanisms of tendon disease and future clinical therapy. Acta Biomaterialia, 63, 18-36. https://doi.org/10.1016/j. actbio.2017.08.032

[21] Summers, S. H., Zachwieja, E. C., Butler, A. J., Mohile, N. V., \& Pretell-Mazzini, J. (2019). Proximal Tibial Reconstruction After Tumor Resection: A Systematic Review of the Literature. JBJS Reviews, 7(7), e1. https://doi.org/10.2106/JBJS.RVW.18.00146

[22] Urakawa, H., Yonemoto, T., Matsumoto, S., Takagi, T., Asanuma, K., Watanuki, M., Takemoto, A., Naka, N., Matsumoto, Y., Kawai, A., Kunisada, T., Kubo, T., Emori, M., Hiraga, H., Hatano, H., Tsukushi, S., Nishida, Y., Akisue, T., Morii, T., Takahashi, M., ... Ozaki, T. (2018). Clinical outcome of primary giant cell tumor of bone after curettage with or without perioperative denosumab in Japan: from a questionnaire for JCOG 1610 study. World Journal of Surgical Oncology, 16(1), Article 160. https://doi.org/10.1186/s12957-018-1459-6

[23] Vaienti, E., Scita, G., Ceccarelli, F., \& Pogliacomi, F. (2017). Understanding the human knee and its relationship to total knee replacement. Acta Biomedica, 88(Suppl. 2), 6-16. https://doi.org/10.23750/abm. v88i2-S.6507

[24] Wu, F., Nerlich, M., \& Docheva, D. (2017). Tendon injuries: Basic science and new repair proposals. EFORT Open Reviews, 2(7), 332-342. https://doi.org/10.1302/2058-5241.2.160075

[25] Vyrva, O. Ye. (2014). Suchasnyi pidkhid do likuvannia zloiakisnykh kistkovykh pukhlyn (ohliad literatury) (Ch. 2) [The current approach to treatment of malignant bone tumors (literature review) (part 2)]. Ortopediya, travmatologiya i protezirovanie, (1), 117-126. https://doi. org/10.15674/0030-598720141117-126 [in Ukrainian].

[26] Vyrva, O. Ye., Ashukina, N. O., Skoryk, I. O., \& Danishchuk, Z. M. (2020). Struktura zv'iazky nakolinka shchuriv za umov yii fiksatsii na rizni poverkhni implantativ [The structure of patella ligament of rats when it is fixed on different implants surfaces]. Ortopediya, travmatologiya $i$ protezirovanie, (1), 78-87. https://doi.org/10.15674/0030-5987202017887 [in Ukrainian].

[27] Vyrva, O. Ye., \& Skoryk, I. O. (2019). Modulne endoprotezuvannia proksymalnoho viddilu velykohomilkovoi kistky $\mathrm{v}$ razi hihantoklitynnoi pukhlyny [Modular endoprosthetics proximal tibia in case of giant cell tumor]. Ortopediya, travmatologiya i protezirovanie, (1), 72-77. https:/l doi.org/10.15674/0030-59872019172-77 [in Ukrainian].

[28] Vyrva, O. E., Golovina, Ya. A. \& Malyk, R. V. (2015). Allokompozitnoe endoprotezirovanie pri khirurgicheskom lechenii patsientov so zlokachestvennymi opukholyami dlinnykh kostei (obzor literatury) [Allograft-prosthesis composite for surgical treatment in patients with malignant tumors of the long bones (review)]. Ortopediya, travmatologiya i protezirovanie, (2), 120-125. https://doi.org/10.15674/0030598720152120-125 [in Russian]. 